\title{
Andrej Tóth - Aleš Skřivan ml. (edd.), Vysoká škola ekonomická v Praze a rok 1968
}

Vysoká škola ekonomická, Praha 2018, 276 s., ISBN 978-80-86781-37-2

Kolektiv autorů z Centra pro dějiny VŠE vydal k příležitosti padesátého výročí událostí roku 1968 publikaci, v níž na pozadí společensko-politického vývoje v reformním období zmapoval roli Vysoké školy ekonomické v Praze v tomto mimořádném roce. VŠE byla ústřední ekonomickou institucí a cílem pedagogů byla nejen přednášková činnost, ale i zapojení do vědeckovýzkumné činnosti v ekonomických disciplínách. Je proto logické, že její pracovníci se aktivně zapojovali do širšího odborného diskurzu k ekonomickým reformám v reformním období, jež propojovaly vědeckovýzkumné a akademické prostředí s politickou sférou.

Cílem práce je primárně seznámit čtenáře s ohlasem událostí roku 1968 na půdě VŠE, respektive představit, jak se její pracovníci zapojovali do reformního procesu a jaký byl ohlas srpnových událostí na škole včetně jejich dozvuků a nastínit širší kontext politicko-společenského vývoje v Československu nejen v reformním období, ale také již po roce 1948. Při zpracování publikace byla využita jak odborná literatura, tak i archivní prameny uložené v Národním archivu a v Centrální spisovně VŠE a také dokumenty, které autoři získali od pamětníků, tehdejších studentů VŠE.

První kapitola Společensko-politická situace v Československu v reformním obdobi (před rokem 1968), jejímž autorem je Lukáš Novotný, uvádí do základní problematiky společensko-politického vývoje v šedesátých letech. Nechybí zde ani základní náčrt hospodářské a politické situace.

Druhá kapitola Společensko-politická situace v roce 1968, jejímž autorem je opět Lukáš Novotný, pojednává o celkovém společensko-politickém vývoji v Československé socialistické republice a detailně mapuje cestu k srpnové invazi vojsk pěti států Varšavské smlouvy do Československa.

Třetí kapitola Shrnuti vývoje československého vysokého školství v obdobi 1945-1968, jejímž autorem je Prokop Závodský, se věnuje vývoji VŠE v průběhu reformního období a roku 1968. Nastiňuje také základní momenty ve vývoji československého vysokého školství po roce 1945 .

Čtvrtá kapitola Vliv KSČ na vývoj vysokých škol v šedesátých letech s důrazem na Vঙ̌E, jejímiž autorkami jsou Jana Švejdová a Petra Holeňová, se pak zabývá vlivem politiky KSČ na vývoj VŠE v šedesátých letech a hlavně v období pražského jara, a to v kontextu celkového vývoje vzdělávací politiky KSČ po roce 1948.

Kapitola K Šikově reformě a významu odborniků z Vysoké školy ekonomické v Praze autorů Kláry Fabiankové, Petra Chalupeckého a Zdenky Johnson přináší pohled na vliv a význam ekonomů z VŠE na tvorbu reformy československé centrálně plánované ekonomiky ve druhé polovině šedesátých let pod vedením ředitele Ekonomického ústavu ČSAV Oty Šika.

Šestá kapitola Rok 1968 na Vysoké škole ekonomické v Praze a jeho dozvuky trojice autorů Andreje Tótha, Jana Hladíka a Aleše Skřivana ml., jež je ústřední kapitolou publikace, se snaží podrobně zmapovat ohlas obrodného procesu, resp. Pražského jara včetně dramatických událostí následujících po vpádu vojsk Varšavské smlouvy do Československa na půdě VŠE. 
Publikaci pak uzavírá kapitola K pưsobení dobrovolných studentských organizací v rámci zajištování zahraničních kontakti̊ studentů VŠE ve druhé polovině šedesátých let autorů Jakuba Drábka a Jana Hladíka. Popisuje studentský život na VŠE - působení dobrovolnických studentských organizací v rámci zajišt'ování zahraničních kontaktů studentů VŠE v polovině šedesátých let.

Publikace je dále opatřena shrnujícím závěrem, přehledem pramenů a literatury, statistickými př́lohami a cizojazyčným resumé. Snadnou orientaci umožňuje jmenný rejstř́ík. Na závěr je připojen seznam zkratek a nechybí ani medailony autorů, načrtávající jejich odborné zaměřní.

Tuto publikaci bych hodnotil jako velmi komplexní, erudovaný a zdařilý př́nos nejen k dějinám vysokých škol, ale také k problematice událostí roku 1968, které jsou pro českou společnost nesmazatelným mementem.

Michal Továrek

doi: $10.14712 / 23365730.2021 .14$

\section{Veronika Stehlíková - Martin Vlach - Luboš Veverka, Tenkrát v listopadu: vzpomínky na Matfyz v čase zlomu MatfyzPres, Praha 2019, 229 s., ISBN 978-80-7378-395-2}

Uvedená publikace kolektivu tří autorů ${ }^{1}$ přináší očima osmnácti osobností pohled na události kolem 17. listopadu 1989 i na události, které jim předcházely. Jedná se zejména o studenty a také o pedagogy Matematicko-fyzikální fakulty Univerzity Karlovy, kteří formou kratších či delších rozhovorů podávají svědectví o tehdejších poměrech na fakultě, popisují, jak byli zapojeni do tehdejšího dění, jak události vnímali, co prožívali, jaké byly jejich naděje a obavy a jak se jim změnil život.

V publikaci nebylo bohužel možné zachytit kompletně pohledy všech pamětníků událostí 17. listopadu. Autoři se proto snažili vybrat osobnosti, které měly „, času zlomu“ nejbliže studentské vůdce a pedagogy, ${ }^{2} \mathrm{z}$ nichž mnozí mohli teprve až po revoluci naplno uplatnit své schopnosti.

1 Veronika Stehlíková je historička moderních dějin, Martin Vlach působí na MFF UK jako docent Kabinetu výuky obecné fyziky, Luboš Veverka je vedoucím Oddělení propagace a mediální komunikace MFF UK.

2 První rozhovor se týká Kamily (*1946) a Marka Bendových (*1968). Kamila Bendová, byla zaměstnankyní Matematického ústavu ČSAV, o tehdejších událostech tedy hovoří z tohoto pohledu. Marek Benda byl v roce 1989 studentem MFF a studentským vůdcem, který pomáhal organizovat průvod z Albertova. Dalšími ze zpovídaných jsou: kvantový teoretik prof. Pavel Cejnar (*1964), tehdejší aspirant, Jiří Dolejší (*1953), jaderný fyzik, tehdejší vědecký pracovník a tajemník katedry, Miroslav Feistauer (*1943), matematik, tehdejší docent Matematického ústavu UK, Eva Hajičová (*1935), lingvistka, v roce 1989 pracovala na katedře analytické matematiky, Milan M. Horák (*1968), kněz, tehdejší student teoretické kybernetiky, Jiří Hořejší (*1951), teoretický fyzik, tehdejší vědecký pracovník, Jan Klíma (*1938), teoretický fyzik a spisovatel, tehdejší osobní asistent, Martin Klíma (*1969), programátor, tehdejší student biofyziky a chemické fyziky, Michal Kopecký (*1968), informatik, tehdejší student teoretické kybernetiky, Antonín Kučera (nar. 1946), matematik, tehdejší odborný asistent, Pavel Lukáč (*1935), profesor fyziky, tehdejší děkan, Libor Pátý (*1929), profesor fyziky, náměstek ministra školství, v roce 1989 docent vakuové fyziky, Jiří Podolský (*1929), profesor vakuové fyziky, tehdy docent na katedře vakuové fyziky, Oldřich Semerák (*1962), profesor astrofyziky, v roce 1989 aspirant, Martin Šmíd (*1970), ekonometr, tehdejší student, omylem (dezinformací) považovaný za obět' demonstrace, a konečně Jiří Veselý (*1940), matematik, tehdy zástupce ředitele Matematického ústavu UK. 